\title{
Low Dose Hyperoxia Primes Airways for Fibrosis in Mice after Influenza A Infection
}

Andrew M. Dylag ${ }^{1 *}$, Jeannie Haak ${ }^{1}$, Rachel Warren ${ }^{2}$, Min Yee ${ }^{1}$, Gloria S. Pryhuber ${ }^{1}$ and Michael A. O'Reilly ${ }^{1}$

${ }^{1}$ Department of Pediatrics, University of Rochester Medical Center, Rochester, New York, USA;

${ }^{2}$ Department of Microbiology and Immunology, University of Rochester Medical Center, Rochester, New York, USA

Running Title: Neonatal Hyperoxia and Airway Disease

Corresponding Author:

Andrew Dylag, MD, FAAP

Division of Neonatology, Department of Pediatrics

Golisano Children's Hospital

University of Rochester Medical Center

601 Elmwood Avenue, Box 651

Rochester, NY 14642

Phone: 585-275-5948

Fax: 585-461-3614

Email: andrew dylag@urmc.rochester.edu

ORCID: 0000-0001-5085-5873

Statement of Financial Support: Supported by a grant from the Strong Children's Research Center at the University of Rochester and National Institutes of Health grant R01 HL091968 (MOR). NIH Center Grant P30 ES001247 supported the animal inhalation facility and the tissue-processing core. The human subject studies were supported by NHLBI Molecular Atlas of Lung Development Program Human Tissue Core grant U01HL122700 and U01HL148861 (G.H. Deutsch, T.J. Mariani, G.S. Pryhuber).

Disclosure Statement: The authors have no financial conflicts to disclose and have agreed to submission of this article.

Category of study: Basic Science

Key words: Influenza A, neonatal hyperoxia, airway hyperreactivity

Abstract: 247 words

Manuscript (not including figure legends): 4542 


\section{Abstract}

2 It is well known that supplemental oxygen used to treat preterm infants in respiratory distress is

3 associated with permanently disrupting lung development and the host response to influenza $A$ virus

4 (IAV). However, many infants who go home with normally functioning lungs are also at risk for

5 hyperreactivity after a respiratory viral infection suggesting neonatal oxygen may have induced hidden

6 molecular changes that may prime to the lung for disease. We discovered that thrombospondin-1 (TSP-

$7 \quad 1$ ) is elevated in adult mice exposed to high-dose neonatal hyperoxia that is known to cause alveolar

8 simplification and fibrotic lung disease following IAV infection. TSP-1 was also elevated in a new, low-

9 dose hyperoxia mouse model (40\% for 8 days; 40x8) that we recently reported causes a transient

10 change in lung function that resolves by 8 weeks of age. Elevated TSP-1 was also identified in human

11 autopsy samples of BPD-affected former preterm infants. Consistent with TSP-1 being a master TGF $\beta$

12 regulator, an early transient activation of TGF $\beta$ signaling, increased airway hyperreactivity, and

13 peribronchial inflammation and fibrosis were seen when 40x8 mice were infected with IAV, which was

14 not seen in infected room air controls. These findings reveal low dose of neonatal hyperoxia that does

15 not affect lung function or structure may still change expression of genes, such as TSP-1, that may

16 prime the lung for disease following respiratory viral infections, and may help explain why former

17 preterm infants who have normal lung function are susceptible to airway obstruction and increased

18 morbidity after viral infection. 


\section{INTRODUCTION}

It is well accepted that early oxygen $\left(\mathrm{O}_{2}\right)$ exposure in preterm infants can disrupt lung development and function in extremely low gestational age newborns (ELGANs, <29 weeks gestation),

22 often resulting in Bronchopulmonary Dysplasia (BPD). Cumulative $\mathrm{O}_{2}$ exposure strongly predicts BPD

23 diagnoses and severity, but approximately 40\% of ELGANs escape the BPD "label" because they are

24 weaned off $\mathrm{O}_{2}$ or respiratory support by 36 weeks' corrected age despite having significant

25 supplemental $\mathrm{O}_{2}$ exposure $(29,60)$. Former ELGANs with and without BPD experience increased

26 morbidity that can be linked to cumulative $\mathrm{O}_{2}$ exposure with increased health care utilization,

27 symptomatic airway disease, and asthma medication use $(18,43,57)$. Former ELGANs are especially

28 vulnerable to respiratory viral infections with increased early childhood hospitalizations for respiratory

29 illnesses $(12,24,51)$ through poorly understood mechanisms. Infection-related lung injury results in

30 airway remodeling and longer-term airway hyperreactivity $(\mathrm{AHR})(26,36,46,65)$, despite increased

31 prescriptions for asthma-related medications $(53,54)$. The airway dysfunction is not bronchodilator

32 responsive, distinguishing it from asthma (23). Thus, there is an urgent need to uncover novel

33 mechanisms responsible for airway dysfunction and wheezing in former ELGANs.

Neonatal hyperoxia is one of the most commonly used exposures in animal models to perturb

35 lung development and model BPD (10). Mice are born in the saccular stage of lung development where

36 airways continue developing and alveolar structure is in its primitive stages, analogous to ELGANs (4).

37 The dose and duration of hyperoxia matters when modeling neonatal $\mathrm{O}_{2}$ exposure in mice. For 38 example, multiple studies, including several from our own laboratory, show that severe hyperoxia ( $\geq$ $3960 \% \mathrm{O}_{2}$ for $\geq 4$ days) creates a BPD-like phenotype $(10,63)$ with alveolar simplification, airway 40 remodeling, and viral susceptibility $(14,25,35,38,40,41,44,49,67)$, even after a long period of room 41 air recovery. These previous models, however, are limited because they often use $\mathrm{O}_{2}$ doses higher

42 than those seen in real-world NICU settings and cause such profound alveolar simplification that it is 43 difficult to discern physiological changes in the airway. This led our laboratory to develop a translational 44 model of low dose chronic hyperoxia $\left(40 \% \mathrm{O}_{2}\right.$ for 8 days; $\left.40 x 8\right)$ which causes transiently increased 45 airway resistance and decreased lung compliance with AHR and airway smooth muscle hypertrophy at 464 weeks (21), consistent with other studies (61). Interestingly, abnormal lung function, AHR, and 
47 smooth muscle hypertrophy all resolve at 8 weeks (21), where mice are morphologically and

48 functionally "normal." Taken together, our model of lower $\mathrm{O}_{2}$ exposures in preterm infants in modern

49 NICUs shows changes in airway function without overt signs of alveolar simplification. We suggest this

50 may more accurately replicate preterm infants with increased respiratory morbidity after leaving the

51 NICU without a diagnosis of BPD.

52 Neonatal hyperoxia also has functional implications when adult mice are challenged with

53 Influenza A viral (IAV) infection. Previous studies by our laboratory have shown that adult IAV infected

54 who received higher dose neonatal hyperoxia (100\% for 4 days, 100x4) at birth experience persistent

55 inflammation and parenchymal fibrosis $(14,25,35,40,41,67)$. We previously showed that $100 \times 4$

56 hyperoxia depletes cardiomyocytes in the lung which has implications on pulmonary hypertension.

57 Secondary analysis of that dataset suggests hyperoxia stimulates extracellular matrix thrombospondin

581 (TSP-1) and several members of the A Disintegrin and Metalloproteinase with Thrombospondin

59 motifs (ADAMTS) family of proteinases which have TSP-1 like activity. Since TSP-1 upregulates TGF $\beta$

60 activity, we hypothesized that $40 \times 8$ adult mice would be primed for increased fibrosis after IAV

61 infection. Herein, we show that when challenged with the HKx31 H3N2 Influenza A Virus (IAV) adult

$6240 \times 8$ mice develop peribronchial fibrosis after infection not observed in room air (RA) controls, that

63 pathologically resolves over time, but persistently decreases lung compliance, thus creating a model of 64 transient morbidity. 
METHODS

Animal Exposures and Infection. All protocols were approved by the Institutional Animal Care

67 and Use Committee of University of Rochester (Rochester, NY) and were consistent with The

68 Association for Assessment and Accreditation of Laboratory Animal Care International policies

69 (Frederick, MD). Litters of C57BI/6J (Jackson Laboratory, Bar Harbor, ME) were placed into room air

70 (RA) or $40 \%$ oxygen from post-natal day (PND) 0-8 as previously described (21). Nursing dams were

71 rotated every 24-48 hours. After exposure, pups were allowed to mature until PND 56 under room air

72 conditions where a subset of naïve mice were harvested for pulmonary function or qRT-PCR analysis.

73 Infected mice were lightly anesthetized with ketamine/xylazine mixture and given $10^{5}$ plaque forming

74 units (PFUs) influenza A (x31/H3N2) virus, which was grown and titered in Madin-Darby Canine Kidney

75 (MCDK) cells as previously described (64). Mice were weighed every other day for two weeks after

76 infection, then weekly thereafter.

Bronchoalveolar Lavage. Bronchoalveolar lavage (BAL) was performed in a subset of animals

78 at post-infection day (PID) 3, 7, 10, and 14 with 3 separate $1 \mathrm{~mL}$ aliquots of ice-cold phosphate-

79 buffered saline (PBS, FisherScientific, Hampton, NH), as previously described (14). The first

80 supernatant was collected for protein analysis and frozen at $-80^{\circ} \mathrm{C}$ for further analysis.

81 Cell differentiation. BAL Fluid (BALF) from all 3 aliquots were combined, then separated by

82 centrifugation with removal of erythrocytes in ammonium chloride lysing solution $\left(0.15 \mathrm{M} \mathrm{NH}_{4} \mathrm{Cl}, 10 \mathrm{mM}\right.$

$83 \mathrm{NaHCO}_{3}, 1 \mathrm{mM}$ EDTA). Total cell count was measured with a TC20 Automated Cell counter (Bio-Rad,

84 Hercules, CA). BALF was then transferred onto slides with a cytological centrifuge (Shandon Cytospin

85 2, Runcorn, UK) and stained with a Hema 3 Stain Set (FisherScientific, Hampton, NH). Images of

86 stained cells were taken with a Nikon E800 microscope (Nikon Instruments Inc., Melville, NY) using a

87 SPOT RT3 Camera and SPOT Imaging Software (v5.2, Diagnostic Instruments, Inc., Sterling Heights,

88 MI). At least 200 cells were counted per slide with ImageJ (NIH, Bethesda, MD).

89 Macrophages/monocytes, neutrophils, and lymphocytes were individually enumerated by two separate 90 investigators.

$91 \quad$ Protein analysis. BALF was analyzed using a DuoSet ELISA kit for Mouse CCL2/JE/MCP-1 and

92 TGF- $\beta 1$ (R\&D Systems, Minneapolis, MN) according to the manufacturer's instructions using a 
93 SpectraMax M5 Microplate Reader (Molecular Devices, San Jose, CA) and Softmax Pro 6.4 (Molecular

94 Devices). The detection range for this assay was $3.9-250 \mathrm{pg} / \mathrm{mL}$. Additionally, latent TGF- $\beta 1$ was

95 activated by incubating samples with $1 \mathrm{~N} \mathrm{HCl}$ and neutralizing with $1.2 \mathrm{~N} \mathrm{NaOH} / 0.5 \mathrm{M}$ HEPES, as per

96 kit instructions, and another ELISA performed to measure immunoreactive TGF- $\beta 1$.

Pulmonary Function Testing. Naïve (8-10 weeks old) and IAV-infected (14 and 56 days postinfection) mice were anesthetized with a ketamine/xylazine mixture [100 mg/kg (Par Pharmaceutical,

99 Chestnut Ridge, NY) and $20 \mathrm{mg} / \mathrm{kg}$ (Acorn, Inc., Lake Forest, IL), respectively], immobilized with 100 pancuronium bromide (10 mg/kg, Sigma-Aldrich, St. Louis, MO), and ventilated (SCIREQ Inc., 101 Montreal, Canada) with a tidal volume of $10 \mathrm{ml} / \mathrm{kg}, 150$ breaths $/ \mathrm{min}, \mathrm{PEEP}$ of $3 \mathrm{~cm} \mathrm{H}_{2} \mathrm{O}$, and $\mathrm{FIO}_{2}$ of $10221 \%$ as previously described (21). Respiratory system resistance $\left(R_{r s}\right)$, Newtonian airway resistance $103\left(R_{N}\right)$, respiratory system compliance $\left(C_{r s}\right)$, Elastance $(H)$, Tissue Damping $(G)$, hysteresivity $(\eta$, eta) 104 were measured in triplicate at both time points.

105 Human Tissues. Donor lungs samples were provided through the federal United Network of 106 Organ Sharing via National Disease Research Interchange (NDRI) and International Institute for 107 Advancement of Medicine (IIAM) and entered into the NHLBI LungMAP Biorepository for Investigations 108 of Diseases of the Lung (BRINDL) at the University of Rochester Medical Center overseen by the IRB 109 as RSRB00047606, as previously described $(5,7)$. Lung tissue sections were uniformly obtained from 110 the right lower lobe of 6 infants, 3 infants born prematurely $(25,26$, and 28 gestational weeks) that died 111 between 84 and 86 weeks post-menstrual age with BPD (2 ventilator dependent, died of respiratory 112 failure, 1 with chronic lung disease, but not vent dependent died of accidental event) and 3 infants, 113 each born full term and died at 74 to 100 weeks post-menstrual age of other non-pulmonary causes (n $114=\square 3$ in each group). No acute viral infections were reported in the past medical history of any infant. 115 Sections $(5 \mu \mathrm{m})$ of formalin inflated, paraffin embedded RLL parenchymal lung tissue blocks were de116 paraffinized, re-hydrated, and stained for Anti-Thrombospondin 1 (ab85762, abcam, Cambridge, UK) 117 and DAPI Fluoromount-G (SouthernBiotech, Birmingham, AL).

118 Immunohistochemistry. At PIDs 14 and 56, right lobes of lungs were snap-frozen for qRT-PCR, 119 and left lobes perfused with 10\% neutral buffered formalin (NBF, Fisher Scientific, Hampton, NH) at 25 $120 \mathrm{~mm} / \mathrm{Hg}$, embedded in paraffin wax, and cut to $4 \mu \mathrm{m}$ thick. Additional samples were taken after saline 
121 flush with 1x PBS, before perfusion with NBF. Lung slices were stained with Hematoxylin and Rubens

122 Eosin-Phloxine (H\&E; Biocare Medical, Concord, CA) and Gomori's Trichrome (Richard-Allan Scientific,

123 San Diego, CA) for collagen.

124 Fluorescent immunohistochemistry was performed with primary antibodies S100A4 (FSP-1)

125 (1:1000, PA5-82322, ThermoFisher Scientific, Waltham, MA), Anti-Influenza A Virus Nucleoprotein (NP;

126 NR-43899, BEl Resources, Manassas, VA) or Anti-Thrombospondin 1 (ab85762, abcam, Cambridge,

127 UK), with secondary antibody AlexaFluor 594 (1:200, A21207, ThermoFisher Scientific) and DAPI

128 Fluoromount-G counterstain to view activated macrophages. Stained images were taken with a Nikon

129 E800 microscope (Nikon Instruments Inc., Melville, NY) using a SPOT RT3 Camera and SPOT Imaging

130 Software (v5.2, Diagnostic Instruments, Inc., Sterling Heights, MI). Photographs were analyzed with 131 ImageJ.

$132 \quad$ Fibroblast and collagen staining. FSP1 and Sirius red staining were quantified using ImageJ.

133 Fluorescent images of each airway were taken under red (FSPI, Sirius red) and blue (DAPI) channels.

134 A threshold for each fluorescence was set, and the same used for all images taken. Airway perimeter

135 was measured to ensure only small airways analyzed, then enlarged by 40 (Sirius red) and $80 \mu \mathrm{m}$

136 (FSP1). Particle area (Sirius red) and number (FSP1) were measured, to determine their prevalence 137 surrounding the airways.

138 qRT-PCR. RNA was extracted from tissue with TRIzol Reagent (Invitrogen, Carlsbad, CA) as 139 previously described (69). Complimentary DNA was run on a C1000 ThermoCycler (Bio-Rad) using a 140 Maxima First Strand cDNA Synthesis Kit (ThermoScientific). Quantitative real-time PCR was performed 141 using iQ SYBR Green Supermix (Bio-Rad) with CFX96 Real-Time System (Bio-Rad). Genes of interest 142 where run on plates with mGapdh as housekeeping gene, and analyzed using the $\Delta \Delta \mathrm{C}_{\mathrm{T}}$ method (33).

143 Three to four samples per treatment were run in duplicate on each plate. Primer sequences can be 144 found in Table 1. 
Statistical Analysis. Statistical analyses were performed in GraphPad Prism (GraphPad

146 Software v8, San Diego, CA). Pulmonary function data was subjected to D'Agostino \& Pearson and

147 Shapiro-Wilk tests for normality, Brown-Forsythe test for variance, and ordinary one-way ANOVA with

148 Tukey's multiple comparisons test for significance. In instances of failed normality or variance, Kruskal-

149 Wallis non-parametic and Dunn's multiple comparisons tests were performed for significance. Weight

150 over time was tested for normality and variance, as described above, and multiple t-tests performed

151 with Holm-Sidak correction. Cell differentiation data and ELISA data was subjected to Shapiro-Wilk test

152 for normality. Holm-Sidak correction for multiple comparisons was used to further test cell differentiation

153 and Kruskal-Wallis non-parametic and Dunn's multiple comparisons tests were performed for

154 significance on ELISA data. qRT-PCR data was analyzed using the $\Delta \Delta \mathrm{C}_{\mathrm{T}}$ method, and graphed as fold-

155 change normalized to $\mathrm{RA}=1 . P$ values of $\leq 0.05$ were considered significant for all analyses

156 performed, and values graphed as mean \pm SEM. 


\section{Results}

158 Molecular differences persist in low-dose hyperoxia-exposed mice after Room Air Recovery

159 RA and 40x8 uninfected (naïve) mice were recovered in room air until 8-10 weeks of age

160 (PND56, Figure 1A). We confirmed that RA and 40x8 animals have similar alveolar and airway

161 structure by histology (Figure 1B), consistent with our laboratory's previously published study (21).

162 Furthermore, pulmonary function, measurements were similar between RA and $40 \times 8$ adult mice at this

163 time point (Figure 1C). To determine whether adult RA and recovered 40x8 lungs had similar gene

164 expression, we examined a previously published Affymetrix array in adult mice who received high-dose

165 (100x4 oxygen at birth for candidate genes (68). Out of 45,109 probes present on the array, 54

166 transcripts were differentially expressed between the RA and the 100x4 mice using a false discovery

167 rate of $10 \%$. Neonatal hyperoxia reduced expression of 43 genes, most of which reflected a loss of

168 pulmonary cardiomyocytes (68). We analyzed the upregulated transcripts for genes regulating

169 inflammation using qRT-PCR and found the extracellular matrix protein thrombospondin 1 (TSP-1) and

170 several members of the A Disintegrin and Metalloproteinase with Thrombospondin motifs (ADAMTS)

171 family of proteinases were upregulated in the high dose $100 \times 4$ model (Figure 1D). TSP-1 and

172 ADAMATS share common functions in their ability to activate latent TGF $\beta$ through conformational

173 change of the latent binding protein that opens the binding site of TGF $\beta$ to its receptor (16). We

174 confirmed that TSP-1 expression is increased $40 \times 8$ in adult mice and did not detect increased ADAMTS

175 proteinases at high enough levels to justify further study (Figure 1D), thus choosing to focus on TSP-1.

177 TSP-1 expression is increased in hyperoxia-exposed mice and humans with BPD

178 To evaluate the prevalence and distribution of TSP-1, tissue sections of naïve $40 \times 8$ mice and

179 BPD-affected human tissue samples were stained with TSP-1 antibody and counterstained with DAPI.

180 In $40 \times 8$ mice, TSP-1 was increased in the alveolar spaces (Figure 2A) but less noticeable around the

181 airways. In humans ( $\mathrm{N}=3$ controls, $\mathrm{N}=3$ BPD lungs), increased TSP-1 was similarly detected in the 182 alveolar spaces of 2/3 BPD infants where staining was much more sparse in control infants (Figure $2 B$ ). 
To determine if key TGF $\beta$ signaling pathway mediators were different between RA and 40x8 animals, qRT-PCR was performed on naïve RA and 40x8 adult mice. We did not observe increased expression of TGF $\beta-R 1$, or any of the canonical SMAD genes (Figures 3A, D, E, and F). Conversely, there was a strong trend for decreased $T g f b-R 2$ and $T g f b-R 3$ in naïve mice before infection (Figures 3B, C).

\section{Oxygen Exposed Mice Have Worse Airway Disease after Influenza Infection}

Since TSP-1 activates TGF $\beta$, we wanted to test the hypothesis that the $40 \times 8$ lung was primed to activate TGF $\beta$ signaling following an insult. We administered IAV to hyperoxia and RA exposed mice as a profibrotic challenge, because IAV causes fibrosis in mice and hyperoxia-exposed infants have increased morbidity after viral infections. To test this hypothesis, adult RA (RA-PBS or RA-x31) and 40x8 $\left(\mathrm{O}_{2}\right.$-PBS or $\mathrm{O}_{2}$-x31) mice were nasally inoculated with $\mathrm{HK} \times 31$ IAV or sham (PBS) (Figure 4A). Infection was confirmed by positive nucleoprotein (NP) staining in the airway club cells, indicating active IAV infection in both RA-x31 and O2-x31 animals (Figure 4B). Two weeks after infection, persistent airway inflammation (Figure 4C) and fibrosis (Figure 4D) were observed in $\mathrm{O}_{2}$-treated animals compared to RA controls. To confirm increased fibrosis in $\mathrm{O}_{2}-\mathrm{x} 31$ animals, Sirius Red collagen staining was performed (Figure 4E), imaged, and quantified in both groups with a focus on the peribronchial spaces. Again, we observed increased Sirius Red staining (Figure 4F) in 40x8 animals 2 weeks postinfection. Weight loss over the first two post-infection weeks were not different between the RA-x31 and O2-x31 groups during the first two post-infection weeks through 8 weeks post-infection, whereas sham animals appropriately did not lose weight (Figure 4G). There were no differences in weight loss 207 weeks post-infection (Figure 4H).

209 infection to determine if the observed histologic findings had a physiologic correlate. At two weeks post 210 infection, 40x8 animals had higher total Respiratory System Resistance $\left(R_{\mathrm{rs}}\right.$, Figure $\left.5 \mathrm{~A}\right)$, Newtonian

211 Airway Resistance $\left(\mathrm{R}_{\mathrm{N}}\right.$, Figure 5B), and Elastance (H, Figure 5E) with decreased Respiratory System 212 Compliance $\left(\mathrm{C}_{\mathrm{rs}}\right.$, Figure 5C). Tissue damping (G, Figure 5D) and hysteresivity (eta, Figure 5F) were 
213 unchanged. The magnitude of the changes in $R_{N}$ (which contributes to $R_{r s}$ ) signify the majority of

214 resistance change is due to changes in airway resistance. Interestingly, at 8 weeks post infection, the

215 resistance changes normalized (Figures 5A-B), whereas the compliance and elastance (Figures 5C,

$2165 \mathrm{E})$ remained persistently abnormal in the $40 \times 8$ animals where the $\mathrm{RA}$ animals returned to their

217 previous levels. This suggests that lung function has reached a new, lower physiologic baseline, even

218 after a long period of room-air recovery.

\section{Oxygen Exposed Mice have Persistent Peribronchial Inflammation}

221 We next sought to determine whether low dose $\mathrm{O}_{2}$ exposure is associated with increased

222 inflammatory cells similar to our previous studies using high-dose (100x4) oxygen (39).

223 Bronchoalveolar Lavage Fluid (BALF) was obtained, spun, and quantified with differential cell counts at

2244 time points during infection: days $3,7,10$, and 14. Though we found a slight increase in total cell

225 counts and neutrophils 7 days post infection in RA-x31 animals (Figure 6A-B), cell counts were

226 otherwise similar between groups at the 3,7 , and 10 day time points. However, $\mathrm{O}_{2}-\mathrm{x} 31$ animals had

227 trends for increased total and macrophage cell counts, 14 days after infection (Figure 6A, 6D).

228 Quantification of MCP-1 protein was similar at all time points during infection (data not shown),

229 distinguishing it from other studies in our laboratory (13), indicating that there may be alternate

230 mechanisms driving increased inflammation in this model. To better characterize the inflammatory cells

231 present around the airways, tissue sections were stained for fibroblast stimulatory protein 1 (FSP1), a

232 marker shown to identify inflammatory subpopulations of macrophages (42). Increased FSP1 staining

233 was concentrated around the small airways at 14 days post infection (Figure 6F) and was detected

234 more frequently in $\mathrm{O}_{2}-\mathrm{x} 31$ animals (Figure 6G). Notably, FSP-1 staining was almost absent in the

235 alveolar spaces with no differences detected between $\mathrm{RA}-\times 31$ and $\mathrm{O}_{2}-\mathrm{x} 31$ animals (data not shown).

236 The histologic, physiologic, and phenotypic differences in 40x8 animals led us to investigate

237 possible mechanisms by which increased inflammation and fibrosis would be present and drive

238 increased pulmonary morbidity after IAV infection. We analyzed BAL fluid for TGF $\beta$ using ELISA and

239 observed a strong trend for increased active/total TGF 3 days post infection that normalized by 7 days

240 (Figure 6E). 


\section{DISCUSSION}

Airway disease in former ELGANs is characterized by increased airflow obstruction in infancy

243 (31), specifically in the mid-to-later forced expiratory flows $(47,52)$. These functional deficits predispose

244 ELGANs to wheezing in infancy and childhood irrespective of their BPD status $(8,9,15,27,28,32,56)$.

245 Since BPD is often defined by need for supplemental $\mathrm{O}_{2}$ near term corrected gestational age (60),

246 many infants who were exposed to $\mathrm{O}_{2}$ escape the BPD diagnosis, but still have significant pulmonary

247 morbidity associated with their extreme prematurity. Our laboratory has performed several clinical

248 studies quantifying cumulative $\mathrm{O}_{2}$ exposure in ELGANs with and without BPD and have shown that

249 ELGANs with increased $\mathrm{O}_{2}$ exposure have worse obstructive lung disease (FEV $0.5 / \mathrm{FVC}$ ratio), but "high"

250 and "low" $\mathrm{O}_{2}$ exposed ELGANs have significant airflow obstruction $\left(\mathrm{FEF}_{75}\right)$ compared to term infants at

251 1-year of age (22). Those functional studies were performed in asymptomatic, well ex-preterm infants,

252 but there is an abundance of evidence that when challenged with a respiratory infection, former

253 ELGANs have more significant lower airway symptoms with wheezing suggesting airflow obstruction

254 and increased rehospitalization rates $(20,55,65)$. These clinical studies emphasize that there is a

255 spectrum of lung disease present in former ELGANs, and thus justifies studying a spectrum of $\mathrm{O}_{2}$

256 exposures in the laboratory that more closely model variant neonatal exposures, focusing on airway

257 pathology to determine their impacts on lung development, function, and response to infection.

dose neonatal hyperoxia to show that mice are primed for airway disease when challenged with

260 respiratory viral infection in adulthood. We chose $40 \%$ oxygen for 8 days because our previous studies

261 showed that $40 \times 8$ mice have transiently increased airway hyperreactivity at 4 weeks of age that

262 resolves by 8 weeks, such that the recovered animal is functionally and phenotypically indistinguishable

263 from RA controls. This distinguishes it from other models wherein prolonged high $\mathrm{O}_{2}$ concentrations

264 cause significant alveolar simplification, making it difficult to discern and isolate differences in airway

265 pathology. Relatively low-dose 40x8 oxygen does not cause significant alveolar simplification, though if

266 left in $40 \%$ oxygen for longer periods subtle changes in alveolar structure are detectable (37). We

267 wanted to test if the "repaired" lung after hyperoxia would respond similarly to a RA animal when

268 challenged with influenza A virus and hypothesized based on other studies from our laboratory (14, 25 , 
$35,40,41,67)$ that there would be persistently altered response to IAV, even after a long period of RA recovery. We chose $\mathrm{HK} \times 31$ strain of influenza because it causes lower-airway symptoms, usually without mortality, and mice respond to IAV similarly compared to humans $(19,30,58)$; unlike some

272 other viruses (e.g. Respiratory Syncytial Virus) more commonly seen in infants that are difficult to 273 model in mice. Our model is robust such that it recapitulates several observations in former ELGANs: 1) $274 \mathrm{O}_{2}$ causes changes in baseline airway mechanics, 2) airway changes are not overwhelmed by alveolar 275 simplification, and 3) $\mathrm{O}_{2}$ exposed mice show increased severity of disease with viral infection. 276 Additionally, many hyperoxia mouse models administer virus right when animals come out of hyperoxia, 277 whereas this model allows for RA recovery and post-hyperoxia lung repair. Our 40x8 infection model 278 occurs long after cessation of oxygen exposure, which has translational strengths to reflect former 279 ELGANs later in infancy. Finally, other published models of airway dysfunction often treat animals with 280 allergen or methacholine to observe differences in AHR. While this has been useful in identifying 281 changes in airway smooth muscle, it may not explain airway disease of prematurity because these 282 children often spontaneously wheeze following viral infections yet medications targeting airway smooth 283 muscle relaxation (bronchodilators) are most often ineffective. Similarly, our infection-related changes 284 are evident at baseline and without methacholine, implicating alternate mechanisms of airway 285 pathology in $\mathrm{O}_{2}$ exposed mice apart from smooth muscle bronchospasm, distinguishing it from asthma.

We showed that 40x8 mice have increased airway-specific fibrotic repair resulting in 287 hyperactive airways, associated with TGF $\beta$ hyperactivation, and delayed inflammatory resolution 288 compared to room air controls. Our laboratory previously established a mouse model of high-dose 289 neonatal hyperoxia (100\% x 4 days; 100x4) followed by adult IAV infection associated with increased 290 MCP1, marked alveolar parenchymal fibrosis, and increased mortality. In this paradigm, 100x4 mice 291 have interstitial fibrosis, enhanced epithelial cell death, and increased mortality when exposed to IAV as 292 adults $(14,25,35,40,41,67)$. These changes were partially attributed to the loss of type II alveolar 293 epithelial cells (AEC2s) (69), but since 40x8 hyperoxia does not cause loss of AEC2s, other 294 mechanisms driving disease severity were considered. IAV infection of $40 \times 8$ mice using the same virus 295 increased morbidity, and was associated with peribronchial fibrosis 2 weeks after infection not observed 296 in RA controls. Pulmonary function was abnormal with increased resistance and elastance and 
297 decreased compliance. We observed delayed clearance of immune cells 2 weeks after infection with

298 increased staining for activated macrophages (fibroblast-specific protein 1, FSP-1 (42)) in 40x8 animals

299 and trends for increased total and macrophage cell count in bronchoalveolar lavage fluid at that time

300 point. IAV infection in $40 \times 8$ mice was not associated with increased weight loss or monocyte

301 chemoattractant protein-1 (MCP-1) (13) (data not shown) as previously reported. Finally, 8 weeks after

302 infection, the resistance changes resolve leaving behind subtle significant changes in compliance,

303 establishing a model of intermittent morbidity that causes a downward shift in baseline lung function

304 after infection in $\mathrm{O}_{2}-\times 31$ animals.

305 The peribronchial fibrosis changes in our model are associated with TGF $\beta$ hyperactivation. The

306 TGF $\beta$ pathway regulates normal alveolar lung development (71). Global/floxed knockouts of TGF $\beta$ or

307 key pathway mediators results in impaired alveolarization (50), but its role in airway development is

308 more poorly defined. TGF $\beta 1$ signals through the canonical SMAD and/or non-SMAD dependent

309 pathways to regulate gene expression, which in the lung can promote ECM collagen deposition and

310 remodeling. The TGF $\beta$ signaling machinery changes both its expression and localization within the lung

311 across developmental stages. Notably, TGF $\beta-R 1$ (receptor 1, ALK5), TGF $\beta-R 2$ (receptor 2), and

312 SMAD3 decrease in expression throughout development, but change localization from vessels to

313 airways as mice age such that when alveolarization is complete very little staining is evident in the

314 alveolar spaces (3). This same study demonstrated that similar processes occur during human

315 development, with most staining evident in the airways or vascular smooth muscle layer for ALK1,

316 TGF $\beta-R 1 / A L K 5$, TGF $\beta-R 2$, and SMAD2. The evolutionary reason behind these changes throughout

317 development have not been fully established, but may be concentrated in the areas of greatest lung

318 growth during alveolarization. Dysregulation of the TGF $\beta$ pathway and its machinery has been

319 implicated in hyperoxia-induced lung injury $(2,59,66)$. Specifically, higher dose $\left(85 \% \mathrm{O}_{2} \times 28\right.$ days)

320 hyperoxia leads to a 4-fold increase and relocalization of the TGF- $\beta 2$ receptor to the airway epithelium

321 (2). Similarly, hyperoxia leads to a 6-fold increase co-SMAD/SMAD4 staining, also notable in the airway

322 epithelium and alveolar septae (2). However, whole lung expression of these TGF $\beta$ pathway

323 components in adult mice after 40x8 hyperoxia, was not increased, which led us to further investigate

324 TSP-1 as a protein of interest. 
Our finding of increased TSP-1 may provide mechanistic insight into IAV-related morbidity in hyperoxia exposed mice and humans with BPD. TSP-1 is a calcium binding ECM glycoprotein first

327 discovered in platelet granules (6) and later localized to many other tissues including the lung (1). TSP-

3281 is synthesized by endothelial cells, fibroblasts, smooth muscle cells, monocytes, and macrophages

329 (34) and interacts with several ECM components including integrins, fibronectin, cell receptors, growth

330 factors (like TGF $\beta-1$ ), cytokines, and proteases $(11,45)$. Antiangiogenesis, smooth muscle proliferation,

331 nitric oxide signaling antagonism, and inflammation regulation are known functions of TSP-1 relevant to

332 the lung (1). TSP-1 is required to form normal airway epithelium, as TSP1-null animals have bronchial

333 epithelial hyperplasia, proximal mucous metaplasia, vascular smooth muscle hyperplasia, club cell

334 hyperplasia, and uncontrolled inflammation (16). In contrast, upregulation of TSP-1 was noted in the

335 preterm ventilated lung on autopsy (17), an in utero model of tracheal occlusion (62) (lung stretch), and

336 other profibrotic diseases, but to our knowledge this has not been further explored in BPD. The BPD

337 model is of particular interest because TSP-1 may play a role in capillary rarefication (also seen in

338 mouse hyperoxia models (70)) and contribute to other hyperoxia-induced diseases such as pulmonary

339 hypertension (48). Indeed, we confirmed increased alveolar staining for TSP-1 in both 40x8 exposed

340 adult mice and BPD-affected human infants. The balanced regulation of TGF $\beta$ is vital for survival as

341 TSP1-null and TGF $\beta$-1-null mice both die of similar phenotypes (pneumonia) within weeks of birth (16).

342 The strikingly similar phenotype of TSP1-null and TGF $\beta-1$-null mice suggest that TSP-1 is the main

343 TGF $\beta$ activator in vivo (16). Together, these previous studies on TSP-1/TGF $\beta$ create a potential "dual

344 priming" effect of neonatal hyperoxia on the airway by the following mechanisms: 1) TGF $\beta$ receptor and

345 signaling molecules localize to the airway throughout development and/or during hyperoxia exposure

346 and 2) increased TSP-1 is primed to hyperactivate TGF $\beta$. Thus, TSP-1 is an intriguing candidate for

347 further study in rodent BPD models and in the extremely preterm infant.

$348 \quad$ Our results suggest low-dose neonatal $\mathrm{O}_{2}$ causes "silent" changes in gene expression with long-

349 term functional consequences after a lung insult such as respiratory viral infection, and that the

350 "repaired" lung still reacts abnormally to a profibrotic stimulus such as IAV. This $40 x 8$ hyperoxia model

351 causes an airway-specific phenotype observed at baseline and drives increased respiratory morbidity

352 after infection, thus recapitulating airway diseases observed in former ELGANs. We can now exploit 
353 this model to better understand the origins of TGF $\beta$ hyperactivation (including TSP-1 as a candidate

354 protein), and determine its source and specificity for the viral responses that may explain infection

355 related morbidity in vulnerable former ELGANs.

357 Acknowledgments

358 The authors would like to acknowledge Ethan David Cohen for his technical assistance and advice

359 regarding the manuscript, and thank Biorepository for Investigation of Neonatal Diseases of the Lung

360 (BRINDL) part of the Clinical and Translational Science Institute Informatics, Research Data Integration

361 and Analytics group, University of Rochester Medical Center, for human tissue samples.

362 We are extremely grateful to the families who have generously given precious gifts to support this

363 research. We thank the members of the LungMAP Consortium for their collaborations and the members

364 of the Pryhuber lab (Amanda Howell, Heidie Huyck, and Cory Poole) who prepared the human lung 365 tissue.

\section{Author Contributions}

367 AMD conceived the study and designed experiments. AMD and JH performed experiments with 368 assistance from MY and RW. AMD and JH interpreted the data and wrote the manuscript. GSP curated 369 the human tissue samples, and revised the manuscript. MOR conceived the study, revised the 370 manuscript. All authors approved of the final version.

\section{Statement of Financial Support}

372 Supported by a grant from the Strong Children's Research Center at the University of Rochester and

373 National Institutes of Health grant R01 HL091968 (MOR). NIH Center Grant P30 ES001247 supported

374 the animal inhalation facility and the tissue-processing core. The human subject studies were supported 375 by NHLBI Molecular Atlas of Lung Development Program Human Tissue Core grant U01HL122700 and 376 U01HL148861 (G.H. Deutsch, T.J. Mariani, G.S. Pryhuber).

\section{Disclosure}

379 The authors declare that no conflict of interest exists. 
1. Adams JC, and Lawler J. The thrombospondins. Cold Spring Harb Perspect Biol 3: a009712, 2011.

2. Alejandre-Alcazar MA, Kwapiszewska G, Reiss I, Amarie OV, Marsh LM, Sevilla-Perez J, Wygrecka M, Eul B, Kobrich S, Hesse M, Schermuly RT, Seeger W, Eickelberg O, and Morty RE. Hyperoxia modulates TGF-beta/BMP signaling in a mouse model of bronchopulmonary dysplasia. Am J Physiol Lung Cell Mol Physiol 292: L537-549, 2007. 3. Alejandre-Alcazar MA, Michiels-Corsten M, Vicencio AG, Reiss I, Ryu J, de Krijger RR, Haddad GG, Tibboel D, Seeger W, Eickelberg O, and Morty RE. TGF-beta signaling is dynamically regulated during the alveolarization of rodent and human lungs. Dev Dyn 237: 259-269, 2008.

4. Amy RW, Bowes D, Burri PH, Haines J, and Thurlbeck WM. Postnatal growth of the mouse lung. J Anat 124: 131-151, 1977.

393 5. Ardini-Poleske ME, Clark RF, Ansong C, Carson JP, Corley RA, Deutsch GH, Hagood JS, Kaminski N, Mariani TJ, Potter SS, Pryhuber GS, Warburton D, Whitsett JA, Palmer SM, Ambalavanan N, and Lung MAPC. LungMAP: The Molecular Atlas of Lung Development Program. American journal of physiology Lung cellular and molecular physiology 313: L733-L740, 2017.

6. Baenziger NL, Brodie GN, and Majerus PW. A thrombin-sensitive protein of human platelet membranes. Proc Natl Acad Sci U S A 68: 240-243, 1971.

7. Bandyopadhyay G, Huyck HL, Misra RS, Bhattacharya S, Wang Q, Mereness J, Lillis J, Myers JR, Ashton J, Bushnell T, Cochran M, Holden-Wiltse J, Katzman P, Deutsch G, Whitsett JA, Xu Y, Mariani TJ, and Pryhuber GS. Dissociation, cellular isolation, and initial molecular characterization of neonatal and pediatric human lung tissues. American journal of physiology Lung cellular and molecular physiology 315: L576-L583, 2018.

8. Baraldi E, Carraro S, and Filippone M. Bronchopulmonary dysplasia: Definitions and longterm respiratory outcome. Early Hum Dev 85: S1-S3, 2009.

9. Been JV, Lugtenberg MJ, Smets E, van Schayck CP, Kramer BW, Mommers M, and Sheikh A. Preterm birth and childhood wheezing disorders: a systematic review and meta-analysis. PLoS Med 11: e1001596, 2014.

10. Berger J, and Bhandari V. Animal models of bronchopulmonary dysplasia. The term mouse models. Am J Physiol-Lung C 307: L936-L947, 2014.

11. Bornstein P. Diversity of function is inherent in matricellular proteins: an appraisal of thrombospondin 1. J Cell Biol 130: 503-506, 1995.

12. Broughton S, Roberts A, Fox G, Pollina E, Zuckerman M, Chaudhry S, and Greenough A. Prospective study of healthcare utilisation and respiratory morbidity due to RSV infection in prematurely born infants. Thorax 60: 1039-1044, 2005.

13. Buczynski BW, Yee M, Martin KC, Lawrence BP, and O'Reilly MA. Neonatal hyperoxia alters the host response to influenza A virus infection in adult mice through multiple pathways. American journal of physiology Lung cellular and molecular physiology 305: L282-290, 2013.

14. Buczynski BW, Yee M, Martin KC, Lawrence BP, and O'Reilly MA. Neonatal hyperoxia alters the host response to influenza A virus infection in adult mice through multiple pathways. Am $J$ Physiol-Lung C 305: L282-L290, 2013.

15. Colin AA, McEvoy C, and Castile RG. Respiratory morbidity and lung function in preterm infants of 32 to 36 weeks' gestational age. Pediatrics 126: 115-128, 2010.

16. Crawford SE, Stellmach V, Murphy-Ullrich JE, Ribeiro SM, Lawler J, Hynes RO, Boivin GP, and Bouck N. Thrombospondin-1 is a major activator of TGF-beta1 in vivo. Cell 93: 1159-1170, 1998.

17. De Paepe ME, Greco D, and Mao Q. Angiogenesis-related gene expression profiling in ventilated preterm human lungs. Exp Lung Res 36: 399-410, 2010. 

TM. Early inspired oxygen and intermittent hypoxemic events in extremely premature infants are associated with asthma medication use at 2 years of age. J Perinatol 39: 203-211, 2019.

19. Doherty PC, Topham DJ, and Tripp RA. Analysing the T cell response to influenza viruses in mouse model systems. Int Congr Ser 1123: 153-165, 1996.

20. Doyle LW, Ford G, and Davis N. Health and hospitalistions after discharge in extremely low birth weight infants. Semin Neonatol 8: 137-145, 2003.

21. Dylag AM, Haak J, Yee M, and O'Reilly MA. Pulmonary mechanics and structural lung development after neonatal hyperoxia in mice. Pediatr Res 2019.

22. Dylag AM, Kopin HG, O'Reilly MA, Wang H, Davis SD, Ren CL, and Pryhuber GS. Early Neonatal Oxygen Exposure Predicts Pulmonary Morbidity and Functional Deficits at One Year. $J$ Pediatr 2020. Accepted.

23. Filippone M, Carraro S, and Baraldi E. The term "asthma" should be avoided in describing the chronic pulmonary disease of prematurity. The European respiratory journal 42: 1430-1431, 2013.

24. Furman L, Baley J, Borawski-Clark E, Aucott S, and Hack M. Hospitalization as a measure of morbidity among very low birth weight infants with chronic lung disease. J Pediatr 128: 447-452, 1996.

25. Giannandrea M, Yee M, O'Reilly MA, and Lawrence BP. Memory CD8(+) T Cells Are Sufficient To Alleviate Impaired Host Resistance to Influenza A Virus Infection Caused by Neonatal Oxygen Supplementation. Clin Vaccine Immunol 19: 1432-1441, 2012.

26. Gien J, and Kinsella JP. Pathogenesis and treatment of bronchopulmonary dysplasia. Curr Opin Pediatr 23: 305-313, 2011.

27. Greenough A. Long-term pulmonary outcome in the preterm infant. Neonatology 93: 324-327, 2008.

28. Halvorsen T, Skadberg BT, Eide GE, Roksund O, Aksnes L, and Oymar K. Characteristics of asthma and airway hyper-responsiveness after premature birth. Pediatric allergy and immunology : official publication of the European Society of Pediatric Allergy and Immunology 16: 487-494, 2005.

29. Higgins RD, Jobe AH, Koso-Thomas M, Bancalari E, Viscardi RM, Hartert TV, Ryan RM, Kallapur SG, Steinhorn RH, Konduri GG, Davis SD, Thebaud B, Clyman RI, Collaco JM, Martin CR, Woods JC, Finer NN, and Raju TNK. Bronchopulmonary Dysplasia: Executive Summary of a Workshop. J Pediatr 197: 300-308, 2018.

30. Hikono H, Kohlmeier JE, Ely KH, Scott I, Roberts AD, Blackman MA, and Woodland DL. T-cell memory and recall responses to respiratory virus infections. Immunol Rev 211: 119-132, 2006.

31. Hoo AF, Gupta A, Lum S, Costeloe KL, Huertas-Ceballos A, Marlow N, and Stocks J. Impact of ethnicity and extreme prematurity on infant pulmonary function. Pediatric pulmonology 49: 679-687, 2014.

32. Kotecha SJ, Edwards MO, Watkins WJ, Henderson AJ, Paranjothy S, Dunstan FD, and Kotecha S. Effect of preterm birth on later FEV1: a systematic review and meta-analysis. Thorax 68: 760-766, 2013.

33. Livak KJ, and Schmittgen TD. Analysis of relative gene expression data using real-time quantitative PCR and the 2(-Delta Delta C(T)) Method. Methods 25: 402-408, 2001.

34. Lopez-Dee Z, Pidcock K, and Gutierrez LS. Thrombospondin-1: multiple paths to inflammation. Mediators Inflamm 2011: 296069, 2011.

35. Maduekwe ET, Buczynski BW, Yee M, Rangasamy T, Stevens TP, Lawrence BP, and O'Reilly MA. Cumulative Neonatal Oxygen Exposure Predicts Response of Adult Mice Infected With Influenza A Virus. Pediatr Pulm 50: 222-230, 2015.

36. Maitre NL, Ballard RA, Ellenberg JH, Davis SD, Greenberg JM, Hamvas A, Pryhuber GS, Prematurity, and Respiratory Outcomes P. Respiratory consequences of prematurity: evolution of a diagnosis and development of a comprehensive approach. J Perinatol 35: 313-321, 2015.

37. Nardiello C, Mizikova I, Silva DM, Ruiz-Camp J, Mayer K, Vadasz I, Herold S, Seeger W, and Morty RE. Standardisation of oxygen exposure in the development of mouse models for 
38. O'Reilly M, Harding R, and Sozo F. Altered small airways in aged mice following neonatal exposure to hyperoxic gas. Neonatology 105: 39-45, 2014.

39. O'Reilly MA, Marr SH, Yee M, McGrath-Morrow SA, and Lawrence BP. Neonatal hyperoxia enhances the inflammatory response in adult mice infected with influenza A virus. American journal of respiratory and critical care medicine 177: 1103-1110, 2008. hyperoxia enhances the inflammatory response in adult mice infected with influenza A virus. Am J Resp Crit Care 177: 1103-1110, 2008. DA, and Lawrence BP. Neonatal Oxygen Increases Sensitivity to Influenza A Virus Infection in Adult Mice by Suppressing Epithelial Expression of Ear1. Am J Pathol 181: 441-451, 2012.

492

42. Osterreicher CH, Penz-Osterreicher M, Grivennikov SI, Guma M, Koltsova EK, Datz C, Sasik R, Hardiman G, Karin M, and Brenner DA. Fibroblast-specific protein 1 identifies an inflammatory subpopulation of macrophages in the liver. Proc Natl Acad Sci U S A 108: 308-313, 2011.

43. Raffay TM, Dylag AM, Sattar A, Abu Jawdeh EG, Cao S, Pax BM, Loparo KA, Martin RJ, and Di Fiore JM. Neonatal intermittent hypoxemia events are associated with diagnosis of bronchopulmonary dysplasia at 36 weeks postmenstrual age. Pediatric research 85: 318-323, 2019.

44. Regal JF, Lawrence BP, Johnson AC, Lojovich SJ, and O'Reilly MA. Neonatal oxygen exposure alters airway hyperresponsiveness but not the response to allergen challenge in adult mice. Pediat Allerg Imm-Uk 25: 180-186, 2014.

501 45. Resovi A, Pinessi D, Chiorino G, and Taraboletti G. Current understanding of the thrombospondin-1 interactome. Matrix Biol 37: 83-91, 2014.

46. Reyburn B, Martin RJ, Prakash YS, and MacFarlane PM. Mechanisms of injury to the preterm lung and airway: implications for long-term pulmonary outcome. Neonatology 101: 345-352, 2012.

506

47. Robin B, Kim YJ, Huth J, Klocksieben J, Torres M, Tepper RS, Castile RG, Solway J, Hershenson MB, and Goldstein-Filbrun A. Pulmonary function in bronchopulmonary dysplasia. Pediatric pulmonology 37: 236-242, 2004.

48. Rogers NM, Ghimire K, Calzada MJ, and Isenberg JS. Matricellular protein thrombospondin-1 in pulmonary hypertension: multiple pathways to disease. Cardiovasc Res 113: 858868, 2017.

49. Royce SG, Nold MF, Bui C, Donovan C, Lam M, Lamanna E, Rudloff I, Bourke JE, and Nold-Petry CA. Airway Remodeling and Hyperreactivity in a Model of Bronchopulmonary Dysplasia and Their Modulation by IL-1 Receptor Antagonist. Am J Resp Cell Mol 55: 858-868, 2016.

50. Saito A, Horie M, and Nagase T. TGF-beta Signaling in Lung Health and Disease. Int J Mol Sci 19: 2018.

51. Sampalis JS. Morbidity and mortality after RSV-associated hospitalizations among premature Canadian infants. J Pediatr 143: S150-156, 2003.

52. Sanchez-Solis M, Garcia-Marcos L, Bosch-Gimenez V, Perez-Fernandez V, Pastor-Vivero MD, and Mondejar-Lopez P. Lung function among infants born preterm, with or without bronchopulmonary dysplasia. Pediatric pulmonology 47: 674-681, 2012.

53. Slaughter JL, Stenger MR, Reagan PB, and Jadcherla SR. Inhaled bronchodilator use for infants with bronchopulmonary dysplasia. Journal of Perinatology 35: 61-66, 2015.

54. Slaughter JL, Stenger MR, Reagan PB, and Jadcherla SR. Utilization of inhaled corticosteroids for infants with bronchopulmonary dysplasia. PloS one 9: e106838, 2014.

55. Smith VC, Zupancic JAF, McCormick MC, Croen LA, Greene J, Escobar GJ, and Richardson DK. Rehospitalization in the first year of life among infants with bronchopulmonary dysplasia. J Pediatr-Us 144: 799-803, 2004.

$530 \quad 27: 13$ s-16s, 1998. 
57. Stevens TP, Dylag A, Panthagani I, Pryhuber G, and Halterman J. Effect of cumulative oxygen exposure on respiratory symptoms during infancy among VLBW infants without bronchopulmonary dysplasia. Pediatric pulmonology 45: 371-379, 2010.

58. Van Reeth K. Cytokines in the pathogenesis of influenza. Vet Microbiol 74: 109-116, 2000.

59. Vyas-Read S, Wang WY, Kato S, Colvocoresses-Dodds J, Fifadara NH, Gauthier TW, Helms MN, Carlton DP, and Brown LAS. Hyperoxia induces alveolar epithelial-to-mesenchymal cell transition. Am J Physiol-Lung C 306: L326-L340, 2014.

60. Walsh MC, Yao Q, Gettner P, Hale E, Collins M, Hensman A, Everette R, Peters N, Miller N, Muran G, Auten K, Newman N, Rowan G, Grisby C, Arnell K, Miller L, Ball B, McDavid G, National Institute of Child $\mathbf{H}$, and Human Development Neonatal Research $\mathbf{N}$. Impact of a physiologic definition on bronchopulmonary dysplasia rates. Pediatrics 114: 1305-1311, 2004.

61. Wang H, Jafri A, Martin RJ, Nnanabu J, Farver C, Prakash YS, and MacFarlane PM. Severity of neonatal hyperoxia determines structural and functional changes in developing mouse airway. Am J Physiol-Lung C 307: L295-L301, 2014.

62. Warburton D, and Kaartinen V. When the lung is stretched, could it be thrombospondin via TGFbetal peptide activation? J Physiol 584: 365, 2007. 63. Warner BB, Stuart LA, Papes RA, and Wispe JR. Functional and pathological effects of prolonged hyperoxia in neonatal mice. Am J Physiol-Lung C 275: L110-L117, 1998.

64. Warren R, Domm W, Yee M, Campbell A, Malone J, Wright T, Mayer-Proschel M, and O'Reilly MA. Ataxia-telangiectasia mutated is required for the development of protective immune memory after influenza A virus infection. Am J Physiol Lung Cell Mol Physiol 317: L591-L601, 2019.

65. Weisman LE. Populations at risk for developing respiratory syncytial virus and risk factors for respiratory syncytial virus severity: infants with predisposing conditions. Pediatr Infect Dis J 22: S3337; discussion S37-39, 2003.

66. Yang HP, Fu JH, Xue XD, Yao L, Qiao L, Hou A, Jin LL, and Xing YJ. EpithelialMesenchymal Transitions in Bronchopulmonary Dysplasia of Newborn Rats. Pediatr Pulm 49: 1112$1123,2014$.

67. Yee M, Buczynski BW, Lawrence BP, and O'Reilly MA. Neonatal Hyperoxia Increases Sensitivity of Adult Mice to Bleomycin-Induced Lung Fibrosis. Am J Resp Cell Mol 48: 258-266, 2013.

560 68. Yee M, Cohen ED, Domm W, Porter GA, Jr., McDavid AN, and O'Reilly MA. Neonatal hyperoxia depletes pulmonary vein cardiomyocytes in adult mice via mitochondrial oxidation. Am $J$ Physiol Lung Cell Mol Physiol 314: L846-L859, 2018.

69. Yee M, Gelein R, Mariani TJ, Lawrence BP, and O'Reilly MA. The Oxygen Environment at Birth Specifies the Population of Alveolar Epithelial Stem Cells in the Adult Lung. Stem cells (Dayton, Ohio) 34: 1396-1406, 2016.

566 70. Yee M, White RJ, Awad HA, Bates WA, McGrath-Morrow SA, and O'Reilly MA. Neonatal 567 hyperoxia causes pulmonary vascular disease and shortens life span in aging mice. Am J Pathol 178: 568 2601-2610, 2011.

569 71. Zhao L, Yee M, and O'Reilly MA. Transdifferentiation of alveolar epithelial type II to type I 570 cells is controlled by opposing TGF-beta and BMP signaling. Am J Physiol Lung Cell Mol Physiol 305: 571 L409-418, 2013. 


\section{$574 \quad$ Figure Legends}

Figure 1. A) Model timeline of hyperoxia exposure and recovery in naïve mice. B) H\&E sections of RA

577 and hyperoxia (40\% for 8 days; 40x8) exposed mice resemble RA controls at PND 56. C) Pulmonary

578 function measurements are similar between RA and 40x8 mice for Respiratory System Resistance

$579\left(R_{r s}\right)$, Newtonian airway resistance $\left(R_{N}\right)$, Respiratory system compliance $\left(C_{r s}\right)$, Tissue Damping $(G)$,

580 Elastance $(H)$, and hysteresivity ( $\eta$, eta). $n \geq 8$ per group. D) qRT-PCR of RA and $40 \times 8$ mice at PND 56

581 shows increased Tsp1 and similar expression levels of other identified candidate genes. Data represent

582 means \pm SEM. ${ }^{* *} p \leq 0.01$. Scale bar $=100 \mu \mathrm{m}$.

584 Figure 2. Lung samples were obtained from C57BL/6J A) mice at PND 56 that were exposed to oxygen

585 at PND 0-8, and B) former premature infants at 1-2 year who passed away from BPD with non-BPD

586 age-matched controls. Slides were stained with antibody to TSP-1 (red) and counterstained with DAPI

587 (blue). White arrows indicate TSP-1+ cells. aw = airway. $\mathrm{N}=3$ samples per group. Scale bar $=100 \mu \mathrm{m}$.

Figure 3. qRT-PCR was performed at PND 56 on naïve RA and 40x8 mice for A) TGFBRI, B)

TGFBRII, C) TGFBR3, D) SMAD2, E) SMAD3, and F) SMAD4/co-smad. Data represent means \pm SEM;

$591 \quad n=3-4$ samples per group.

593 Figure 4. A) Experimental timeline for $\mathrm{O}_{2}$ exposure and IAV exposures. At PND 56, mice previously 594 exposed to RA or $40 \times 8$ at PND $0-8$, were intranasally infected with $10^{\wedge} 5$ PFU of H3N2 HKx31 IAV or 595 PBS (sham). B) Fluorescent NP (red), counterstained with CCSP (green) and DAPI (blue), at PID3 596 indicates viral infection in small airways of both treatment groups. C) H\&E and D) Trichrome stains at

597 PID 14 indicate increased inflammation and fibrosis around the small airways of $\mathrm{O}_{2}-\mathrm{x} 31$ animals. E) 598 Sirius red staining at 2 weeks post-infection shows increased collagen deposition in the $\mathrm{O}_{2}-\mathrm{x} 31$ 599 treatment group. F) Increased Sirius red staining was detected around $\mathrm{O}_{2}-\mathrm{x} 31$ airways compared to

600 RA. G) Animals of both groups that received IAV lost significantly more weight than sham mice, but 601 similar weight loss occurred between infected groups. H) H\&E staining at PID 56 showed a recovered 
602 phenotype with resolved inflammation and fibrosis for both groups. Data represent means \pm SEM; $n \geq 5$

603 samples per group. Scale bars $=100 \mu \mathrm{m}$. PND $=$ post-natal day, PID = post-infection day.

605 Figure 5. Pulmonary function testing at PID14 and 56. A) $R_{r s}$ and B) $R_{N}$ were higher in the O2-x31

606 group at PID14 indicating more hyperactive airways. C) $\mathrm{C}_{\mathrm{rs}}$ was decreased in $\mathrm{O}_{2}-\mathrm{x} 31$ animals at both

607 time points D) $\mathrm{G}$ was unchanged at both time points E) $\mathrm{H}$ was increased at both time points indicating

608 increased tissue stiffness F) $\eta$ remained unchanged at both time points indicating homogenous lung

609 disease. Data represent means \pm SEM; $n \geq 8$ samples per group. * $p \leq 0.05$. $\mathrm{R}_{\mathrm{rs}}$ - respiratory system

610 resistance, $R_{N}-$ Newtonian resistance, $C_{r s}$ - respiratory system compliance, $\mathrm{G}$ - tissue damping, $\mathrm{H}$ -

611 tissue elastance, $\eta($ eta) - hysteresivity.

612 Figure 6. BALF was collected at PID 3, 7, 10, and 14 from RA-x31 and $\mathrm{O}_{2}-\mathrm{x} 31$ animals. A). Total cells,

613 B) neutrophils C) lymphocytes, and D) macrophages were enumerated. Total cells were increased in

614 the RA-x31 group at PID 7 and trends for increased total cells and macrophages were present at PID

615 14. E) ELISA was performed to determine ratio of activated/total TGF- $\beta 1$ on PIDs 3 and 7 BALF. A

616 trend towards a significant increase in $\mathrm{O}_{2}$-x31 protein at PID 3 was seen. PID 14 lung slices were

617 stained with antibodies to FSP-1 (red) and DAPI (blue). F) More FSP-1+ cells were present around $\mathrm{O}_{2}$ -

$618 \times 31$ airways group compared to RA-x31 controls. Data represent means \pm SEM; $n \geq 5$ samples per

619 group. $\# \mathrm{p}<0.10$ (trend), ${ }^{\star} p \leq 0.05,{ }^{*} p \leq 0.01$. 


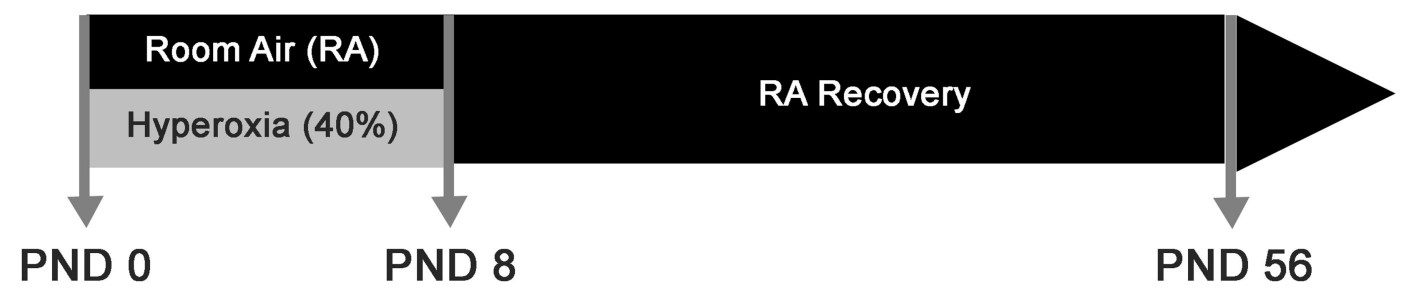

B

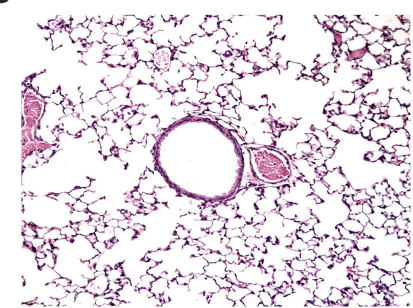

RA

D

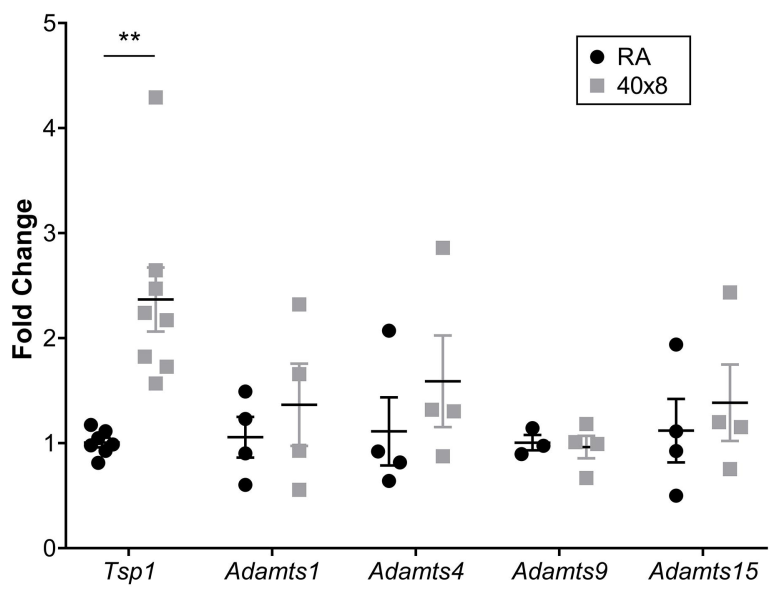

C
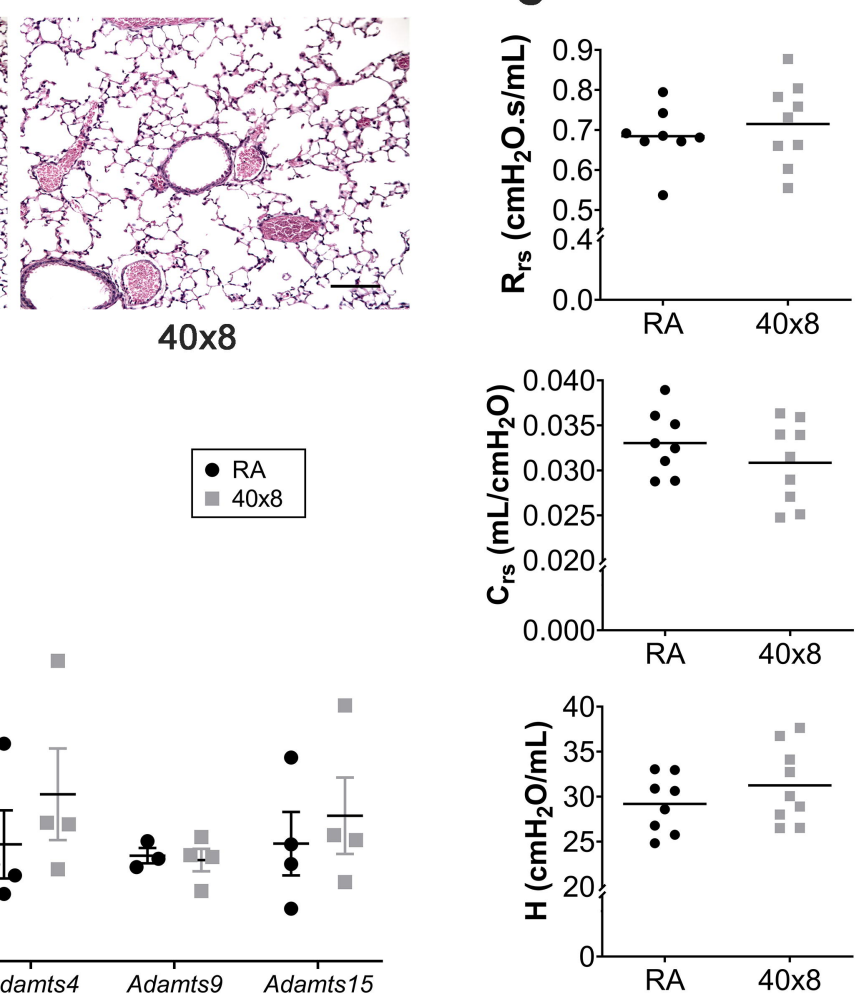
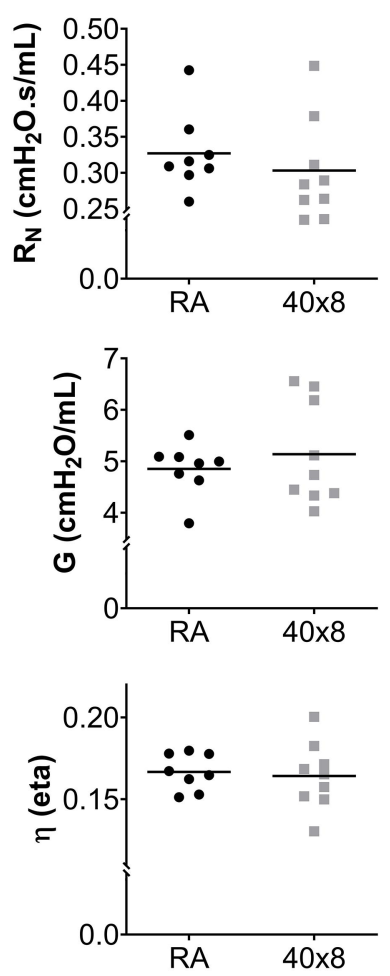


\section{Tgfb-R1}

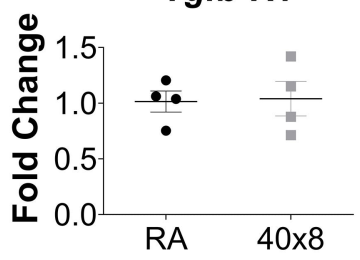

D

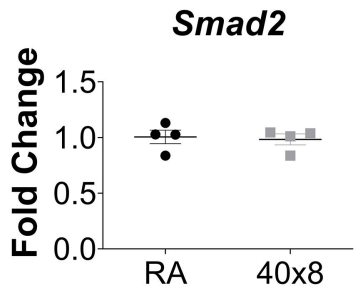

\section{Tgfb-R2}

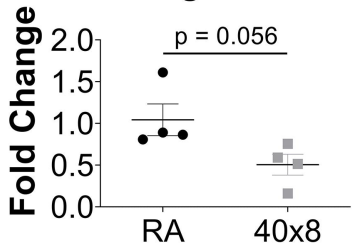

E

Smad3

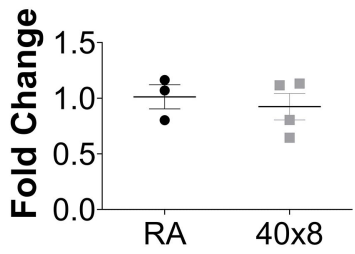

Tgfb-R3

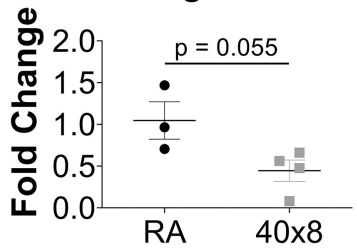

F

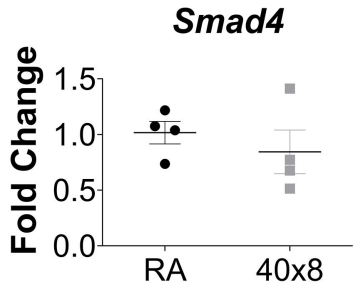



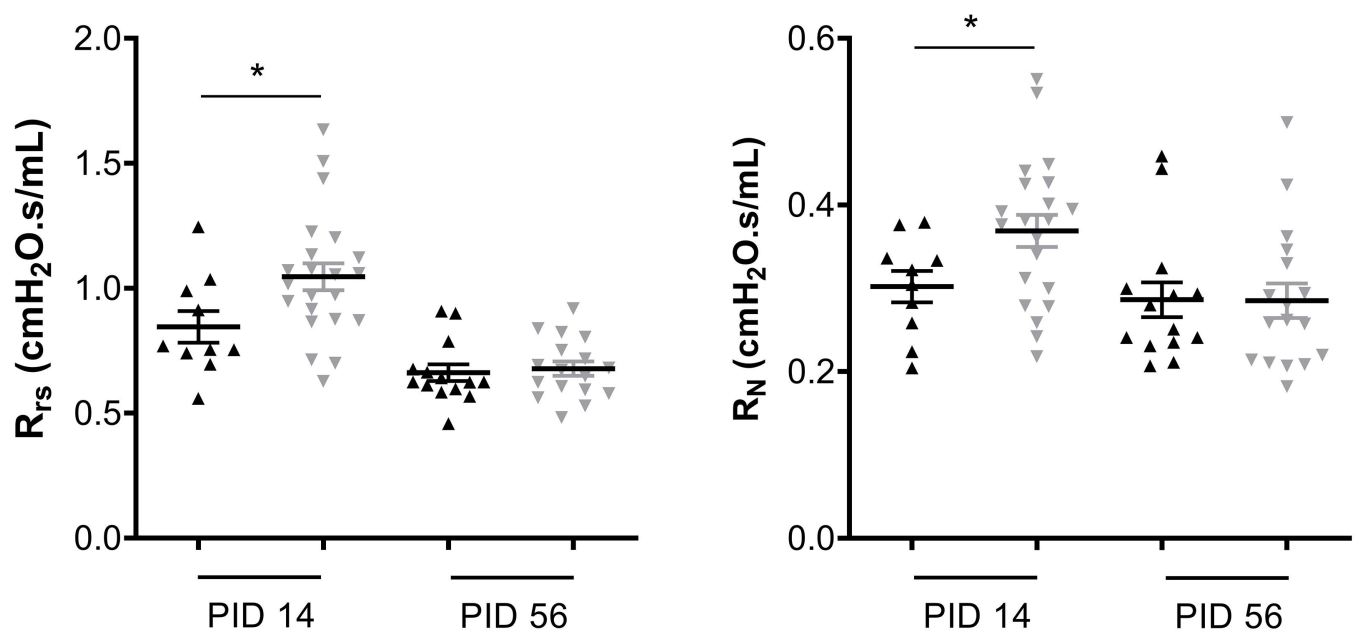

C

D
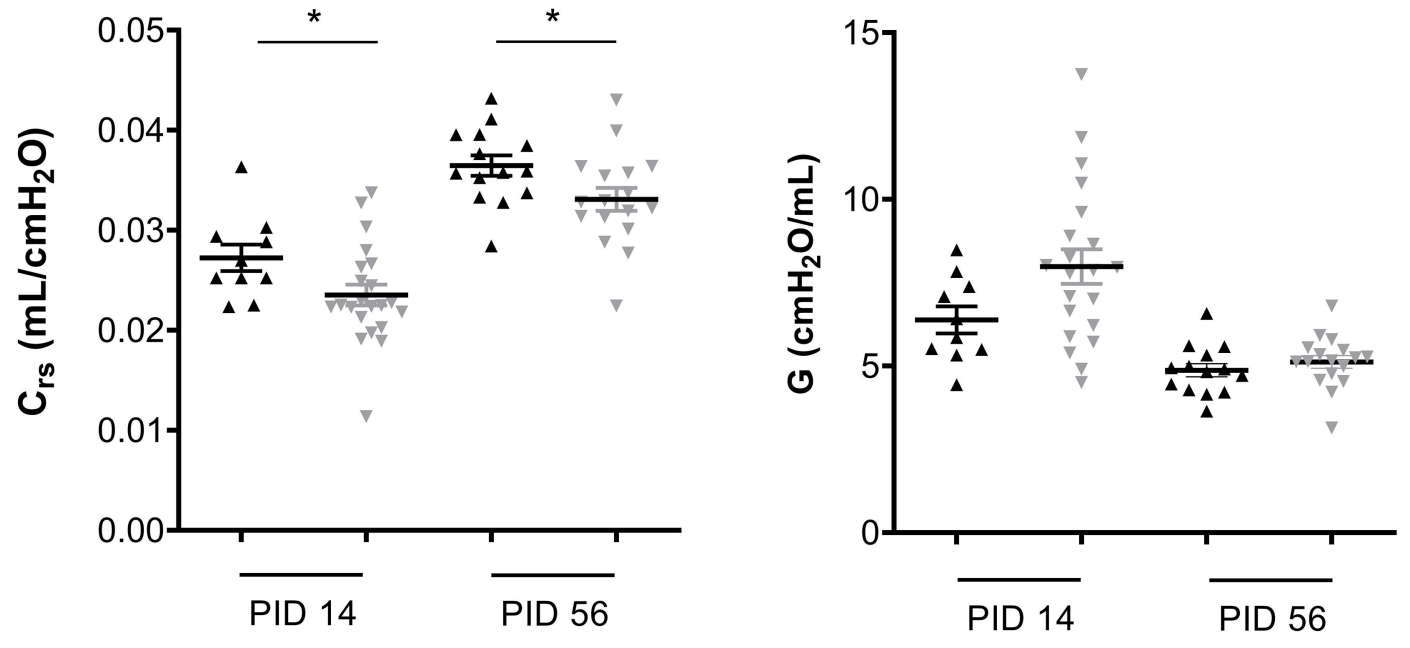

E

F
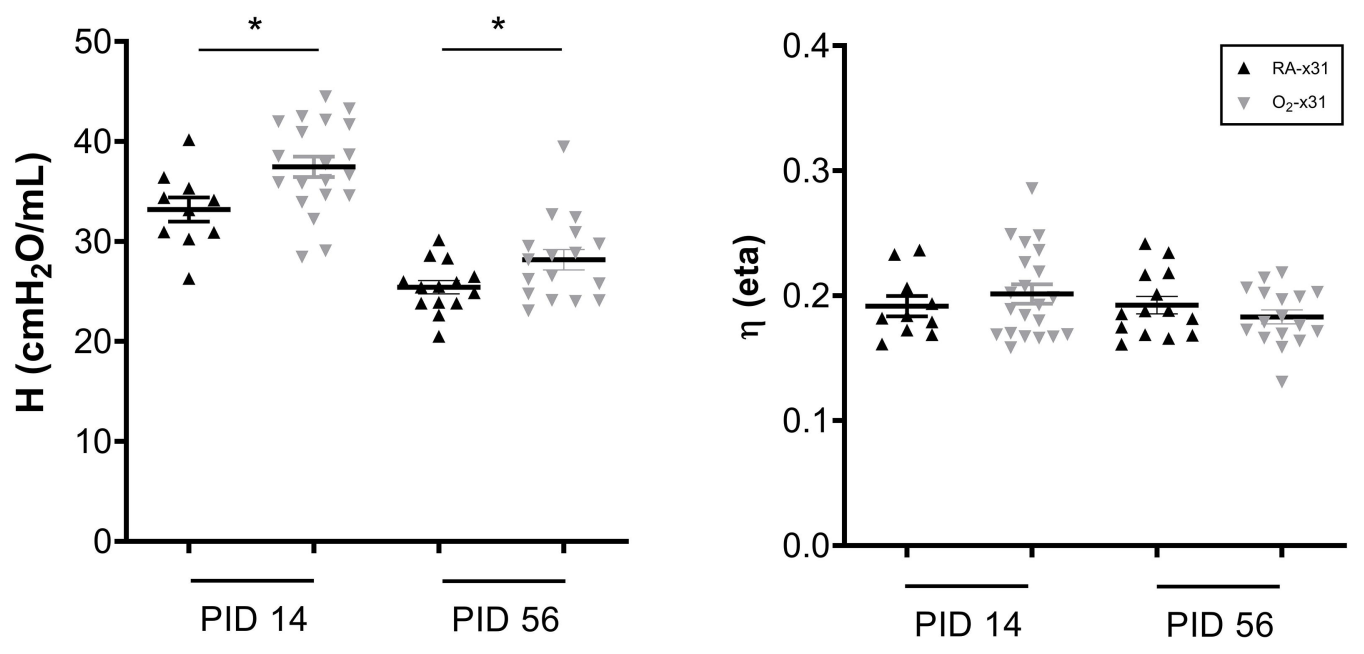


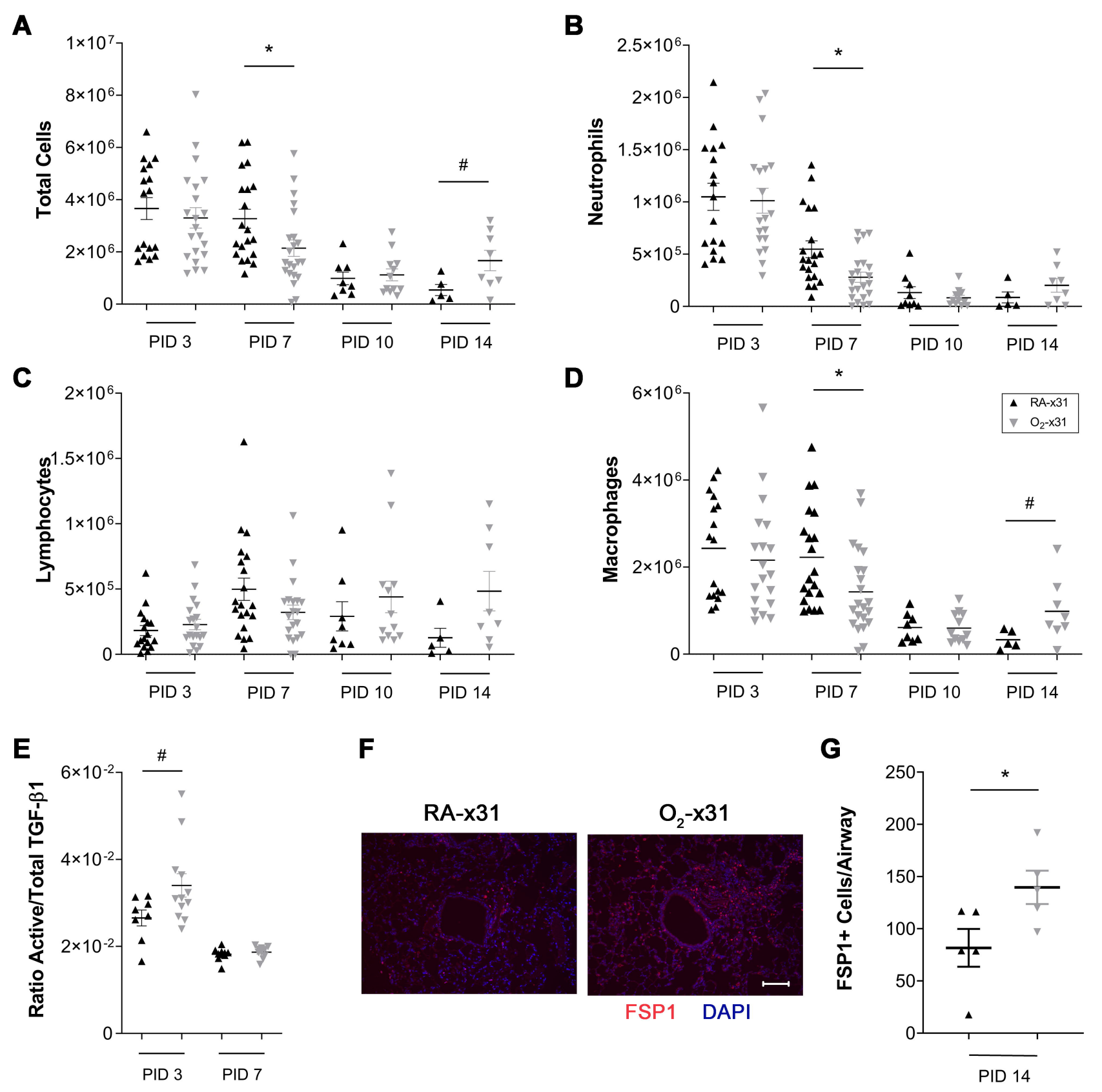


3 Table 1. qRT-PCR Primer Sequences.

\begin{tabular}{|c|c|c|}
\hline Primer & Forward (5' - 3') & Reverse (5’ - 3') \\
\hline$m T s p-1$ & TCC CCT ATT CTG GAG GGT TC & TCC CTG GAA ATA GGC ACA AG \\
\hline mAdamts1 & CTC GTA GCT GAC CAG TCC AT & ACT TCT GGT CCC TTC TGC TC \\
\hline mAdamts4 & CAG ACG AAG CAC TCA CCT T & CCA GCC TGA GGA ACA TTG A \\
\hline mAdamts9 & GCC TGT GCT ACC TTA CCT AAA C & CCA CAA GTC ACG GAA CAA GAG \\
\hline mAdamts15 & TGA TCT GTC TCC GAC CCT CA & GAC TCA CCA TGC CCA CT \\
\hline$m T g f \beta-R 1$ & AAA ACA GGG GCA GTT ACT ACA AC & TGG CAG ATA TAG ACC ATC AGC A \\
\hline$m T g f \beta-R 2$ & AAC ATG GAA GAG TGC AAC GAT & CGT CAC TTG GAT AAT GAC CAA CA \\
\hline$m T g f \beta-R 3$ & GGT GTG AAC TGT CAC CGA TCA & GTT TAG GAT GTG AAC CTC CCT TG \\
\hline mSmad1 & ACC CCT ACC ACT ATA AGC GAG & TGC TGG AAA GAG TCT GGG AAC \\
\hline mSmad2 & ATG TCG TCC ATC TTG CCA TTC & AAC CGT CCT GTT TTC TTT AGC TT \\
\hline mSmad3 & CAC AGC CAC CAT GAA TTA CGG & TGG CGT CTC TAC TCT CTG ATA GT \\
\hline mSmad4 & CAT TCC AGC GTG CCA TTT C & TTC AAA GTA AGC AAT GGA GCA C \\
\hline mGapdh & TGT CCG TCG TGG ATC TGA C & CCT GCT TCA CCA CCT TCT TG \\
\hline
\end{tabular}

